\title{
IMPLEMENTASI KEBIJAKAN PROGRAM PAMSIMAS (PENYEDIAN AIR MINUM DAN SANITASI BERBASIS MASYARAKAT)
}

\author{
Vifin Rofiana \\ Praktisi \\ Staf Kementerian Ketenagakerjaan R.I \\ rofianavifin@yahoo.com
}

\begin{abstract}
ABSTRAK
Air merupakan kebutuhan dasar bagi manusia, tetapi kenyataannya tetap bahwa tidak semua orang memiliki akses ke air bersih dan sehat memadai, sesuai dengan kebutuhannya. Masalah air dan sanitasi yang buruk di Indonesia menelurkan Program Pamsimas. Tujuan Program Pamsimas adalah untuk meningkatkan akses air minum dan sanitasi bagi masyarakat miskin di pedesaan dan pinggiran kota, serta meningkatkan nilai dan perilaku hidup sehat dengan membangun / menyediakan prasarana dan sarana air minum dan sanitasi berbasis masyarakat yang berkelanjutan dan dapat diadopsi oleh orang-orang untuk mencapai MDGs sasaran. Atas dasar ini, perlu untuk memeriksa pelaksanaan Air Bersih dan Sanitasi Berbasis Masyarakat.
\end{abstract}

Kata Kunci: Implementasi, PAMSIMAS, Pengembangan, Sanitasi.

\begin{abstract}
Water is a basic need for human beings, but the fact remains that not all people have access to clean and healthy water adequately, according to his needs. The problem of water and poor sanitation in Indonesia spawned Pamsimas program. Purpose Pamsimas program is to improve access to drinking water and sanitation for the poor in rural and peri-urban, as well as increase the value and healthy behavior by building / providing infrastructure and facilities for drinking water and sanitation community-based sustainable and can be adopted by people in order to achieve the target MDGs. On the basis of this, it is necessary to examine the implementation of Water Supply and Sanitation Community-Based.
\end{abstract}

Keywords : Implementation, PAMSIMAS, Development, Sanitation. 


\section{PENDAHULUAN}

\begin{tabular}{l}
\multicolumn{4}{c}{ "Bumi, air dan kekayaan alam } \\
yang terkandung di dalamnya \\
dikuasai oleh negara dan
\end{tabular}
dipergunakan untuk sebesar-besar kemakmuran rakyat" (UUD pasal 33 ayat 3) merupakan suatu pembuktian hukum atas hak dasar setiap WNI untuk memanfaatkan kekayaan negara untuk kesejahteraan hidupnya. Segala kekayaan yang dimiliki Negara termasuk kekayaan sumber daya air wajib dan mutlak dikelola Negara dan diperuntukkan untuk memenuhi kebutuhan masyarakat tanpa perkecualian. Akan tetapi, jutaan warga di berbagai daerah di Tanah Air masih kesulitan mengakses air bersih karena keterbatasan infrastruktur yang ada.

Akibatnya, kebutuhan akan air menjadi sesuatu yang harus dibayar mahal, dengan kemampuan ekonomi masyarakat kecil yang rendah, akses air bersih merupakan hal yang luar biasa berharga, mengingat kehidupan mereka yang lekat dengan sumber air sungai yang keruh dan bercampur limbah. Sebagian besar masyarakat masih terbiasa dengan pola hidup yang jauh dari kata sehat. Sampai saat ini, banyak masyarakat, terutama masyarakat pedesaan, pinggiran perkotaan, pinggiran sungai dan masyarakat yang tinggal di daerah rawan dan terpencil yang kekurangan akses air bersih menggunakan air kotor untuk kebutuhan sehari-hari. Air ini bercampur dengan sampah, limbah, bahkan tinja. Air untuk mencuci, masak, mandi, buang hajat, hingga minum berasal dari sumber sungai yang sama. Hal ini terjadi karena kurangnya fasilitas sanitasi yang memadai bagi masyarakat.

Hasil studi Water and Sanitation Program (WSP) Bank Dunia (2008) menyebutkan bahwa Indonesia berpotensi mengalami kerugian ekonomi sebesar Rp 58 Triliun per tahun atau sekitar Rp 225 ribu per rumah tangga akibat kondisi sanitasi yang buruk. Masyarakat dan pola hidup yang tidak sehat sebagian besar disebabkan karena paksaan untuk tetap survive di tengah krisis air dan minimnya sarana infrastruktur yang disediakan pemerintah.

Sebagai jalan keluar dari permasalahan ini, sejak 2006 pemerintah memperkenalkan program penyediaan air bersih dan sanitasi dengan pendekatan sanitasi total. Pemerintah berkomitmen memberikan fasilitas penyediaan air dan mengelola sanitasi serta kesehatan lingkungan dengan menerapkan strategi Sistem Penyediaan Air Minum yang mencakup program nasional Penyediaan Air Minum dan Sanitasi Berbasis Masyarakat (PAMSIMAS).

Dengan demikian dalam penelitian ini berusaha mengkaji lebih detail tentang "Implementasi Kebijakan Program PAMSIMAS 
(Penyedian Air Minum dan Sanitasi Berbasis Masyarakat) sebagai Salah Satu Program Pembangunan Kesehatan Masyarakat".

1. Identifikasi Isu/ Permasalahan yang Berkembang

Terdapat isu isu strategis yang diperkirakan akan mempengaruhi upaya Indonesia membentuk berbagai program pro masyarakat, termasuk PAMSIMAS untuk mencapai target pembangunan air minum dalam kerangka MDG pada tahun 2015. Isu-isu yang berkembang ini turut melatarbelakangi berbagai program yang dilaksanakan pemerintah, terutama berkaitan dengan pelestarian sumber daya air dan penyediaan air bagi masyarakat. Isu-isu tersebut dijelaskan dibawah ini.

2. Daya Dukung Lingkungan Semakin Terbebani oleh Pertumbuhan Penduduk dan Urbanisasi

Pada tahun 2015, jumlah penduduk Indonesia diperkirakan mencapai 245,7 juta jiwa, yang semuanya berhak mendapatkan akses air minum. Pada tahun 2015, jumlah penduduk perkotaan menjadi lebih besar dibandingkan dengan perkotaan dengan perbandingan $53 \% 47 \%$. Tentunya pergeseran ini mengindikasikan semakin meningkatnya kebutuhan akan air minum per kapita, karena konsumsi air masyarakat perkotaan lebih besar daripada masyarakat perdesaan. Pertumbuhan penduduk terutarna diperkotaan lebih tinggi daripada pertumbuhan sarana penyediaan air minum yang ada. Sementara itu penduduk di pulau Jawa akan meningkat dengan cepat, sementara ketersediaan airnya sangat terbatas.

Penggundulan hutan telah tidak terkendali sehingga semakin mengganggu ketersediaan air baku. Sedangkan sumber air baku terutarna air permukaan mengalarni pencemaran yang semakin meningkat akibat domestik, industri dan pertanian. Sehingga ketersediaan air baku semakin tidak bisa dijamin, baik kuantitas dan kualitas. Air baku di sebagian besar wilayah Indonesia sebenarnya tersedia dengan cukup, tetapi terancam keberadaannya akibat pengelolaan yang buruk, baik oleh pencemaran maupun kerusakan alam yang menyebabkan terhambatnya konservasi air.

Di sebagian wilayah Indonesia seperti Kalimantan dan sebagian Sumatera air baku sulit diperoleh karena kondisi alamnya sehingga masyarakat harus mengandalkan air hujan Page | 173 
atau air permukaan yang tidak sehat. Akibat kerusakan alam, semakin banyak wilayah yang rawan bencana air, kekeringan di musim kemarau dan kebanjiran di musim hujan.

3. Interpretasi UU No 22 Tahun 2004 Tidak Mendorong Pengembangan dan Kerjasama Antar Daerah Dalam Penyediaan Air Minum.

UU No 7/2004 tentang Sumber Daya Air telah mengamanatkan dibentuknya Dewan Air untuk manajemen air secara terpadu dan Badan Pengatur untuk mengurusi air minum. Tetapi hingga saat ini lembaga lembaga tersebut belum terbentuk. Belum adanya lembaga yang mengatur tata guna air secara terpadu menyebabkan persoalan air di Indonesia ditangani secara sektorat sehingga tidak terarah dan tidak terintegrasi. Dengan otonomi daerah, kewenangan penyediaan air adatah pada pemerintah daerah. Tetapi kebanyakan pemerintah daerah belum memandang air sebagai persoalan prioritas.

Pemekaran wilayah yang berdampak pada pemekaran PDAM, sehingga terbentuk PDAM berukuran kecil dan cenderung tidak efisien, ditambah lagi permasalahan sumber air baku terletak diluar batas administrasi pengelola PDAM, sehingga menjadi kendala untuk peningkatan pelayanan.

4. Kebijakan Yang Memihak Kepada Masyarakat Miskin Masih Belum Berkembang

Pada dasarnya negara menjamin hak setiap orang untuk mendapatkan air bagi kebutuhan pokok minimal sehari hari guna memenuhi kehidupan yang sehat, bersih dan produktif (UU No 7 tahun 2004, pasal 10). Namun pada kenyataannya presentase penduduk miskin masih tinggi, sehingga kemampuan untuk mendapat akses kesarana penyediaan air minum yang memenuhi syarat masih terbatas. Masyarakat berpenghasilan rendah, ternyata membayar lebih besar untuk memperoleh air daripada masyarakat berpenghasilan tinggi, hal ini menunjukkan ketidakadilan dalam mendapatkan akses pada air minum.

Walaupun sudah terdapat program program air minum dan sanitasi untuk masyarakat berpenghasilan rendah, namun akses terhadap air minum belum menunjukkan peningkatan yang berarti. Perlu dukungan kebijakan yang lebih fokus untuk penyediaan sanitasi dan 
air minum bagi masyarakat berpenghasilan rendah.

5. PDAM Tidak Dikelola Dengan Prinsip Kepengusahaan

Air minum perpipaan sebagai sistem pelayanan air minum yang paling ideal hingga saat ini baru dapat dinikmati oleh sebagian kecil masyarakat Indonesia. Secara nasional, cakupan air perpipaan baru sekitar 17\%, meliputi $32 \%$ di perkotaan dan $6,4 \%$ di perdesaan. Pada umumnya PDAM secara rata rata nasional mempunyai kinerja yang belum memenuhi harapan. Seperti tingkat pelayanan yang rendah (32\%), kehilangan air tinggi (41\%), konsumsi air yang rendah (14 m3/bulan/RT).

Biaya produksi tergantung dari sumber air baku yang digunakan oleh PDAM. Namun secara umum biaya produksi untuk sernua jenis air baku ternyata lebih tinggi daripada tarif. PDAM yang menggunakan mata air sebagai sumber air baku, biaya produksi rata rata $\mathrm{Rp} 787 / \mathrm{m} 3$, sedangkan tarif rata-rata $\mathrm{Rp} \quad 61 \quad 8 / \mathrm{m} 3$. PDAM yang menggunakan mata air, sumur dalam dan sungai sekaligus, biaya produksi rata rata $\mathrm{Rp} 1.188 / \mathrm{m} 3$, dan tarif rata rata $\mathrm{Rp} 1.112 / \mathrm{m} 3$. Sedangkan PDAM yang mengandalkan sungai sebagai sumber air baku, biaya produksi rata rata $\mathrm{Rp}$ $1.665 / \mathrm{m} 3$, dan tarif rata rata $\mathrm{Rp}$ $1.175 / \mathrm{m} 3$.

PDAM belum mandiri karena campur tangan pemilik (Pemda) dalam manajemen dan keuangan, hal ini cukup membebani PDAM. Sumber daya manusia pengelola PDAM umumnya kurang profesional sehingga menimbulkan inefisiensi dalam manajemen. Dari segi keuangan, tarif air saat ini tidak bisa menutup biaya operasi PDAM, sehingga PDAM mengalami defisit kas, dan tidak mampu lagi menyelesaikan kewajibannya. PDAM masih mempunyai hutang jangka panjang yang cukup besar dan tidak terdapat penyelesaian yang memuaskan.

Banyak PDAM yang mengabaikan pelayanan dan kepentingan pelanggan, keluhan pelanggan sering tidak ditanggapi dengan baik oleh PDAM, pelanggan merasa tidak berdaya. Hal ini menandakan kedudukan antara konsumen dan produsen tidak setara. Walaupun dibeberapa PDAM sudah terbentuk forum pelanggan/konsumen, namun perannya belum maksimal, belum dianggap mitra kerja PDAM yang potensial.

Pengawasan/akuntabititas terhadap pengelolaan penyedia 
air minum masih lemah, belum ada sanksi untuk penyelenggara air minum yang tidak memberikan pelayanan sesuai dengan syarat yang ditentukan. Badan pengawas masih lemah/kurang berfungsi. Berdasarkan uraian diatas, dari 300 lebih PDAM yang ada di Indonesia, sebagian besar mengalami kendala dalam memberikan pelayanan yang baik akibat berbagai persoalan, baik aspek teknis (air baku, unit pengolah dan jaringan distribusi yang sudah tua, tingkat kebocoran, dan lain lain) maupun aspek non teknis (status kelembagaan PDAM, utang, sulitnya menarik investasi swasta, pengelolaan yang tidak berprinsip kepengusahaan, dan lain lain).

6. Kualitas Air Belum Memenuhi Syarat Air Minum

Kualitas yang diterima pelanggan dari PDAM masih berkualitas air bersih, belum memenuhi syarat kualitas air minum. Padahal didalam peraturan sudah diisyaratkan bahwa yang dimaksud dengan air minum adalah air yang bisa dikonsumsi tanpa dimasak terlebih dahulu.

Masyarakat tidak memahami akan hak haknya untuk memperoleh air yang sesuai dengan persyaratan air minum yang ada, sehingga masyarakat sering menerima saja apa yang diterima dari penyedia air minum. Sedangkan PDAM tidak pernah menginformasikan kualitas air minum yang mereka sediakan kepada masyarakat. Apabila masyarakat bisa memperoleh air dengan kualitas air minum, diperkirakan angka penyakit yang ditularkan atau yang berhubungan dengan air akan bisa berkurang $80 \%$.

7. Keterbatasan Pembiayaan Mengakibatkan Rendahnya Investasi Dalam Penyediaan Air Minum

Sampai tahun 1996 masih terdapat investasi yang cukup berarti dalam penyediaan air minum, yang meliputi hibah pemerintah (pusat dan daerah), dan pinjaman dalam dan luar negeri. Sejak itu kemampuan pemerintah semakin terbatas dalam membiayai investasi sarana penyediaan air minum, termasuk pula pinjaman baik dari dalam maupun luar negeri. Investasi dalam bidang air minum sangat tergantung dari pinjaman dari dalam negeri dan terutama dari luar negeri. Sementara sumber sumber keuangan untuk investasi melalui pinjaman semakin terbatas, dan akan semakin terhambat oleh hutang PDAM, 
apabila tidak terdapat penyelesaian yang mernuaskan.

Apabila untuk sektor perumahan terdapat pembiayaan yang murah untuk pembangunannya, bahkan dimasa yang lalu pernah didanai melalui Kredit Likuiditas Bank Indonesia, sektor air minum yang merupakan hajat hidup orang banyak tidak terdapat sumber dana murah yang bisa diakses oleh PDAM. Sumber pembiayaan sampai saat ini masih mengandalkan pinjaman dan hibah yang semakin terbatas jumlahnya, dan belum berkembang sumber pendanaan alternatif seperti obligasi. Dilain pihak terdapat Pemerintah Kota/Kabupaten yang mempunyai pendapatan yang tinggi dari PAD atau Bagi Hasil (PPn, PPh, dan PBB), namun kurang mempunyai perhatian terhadap pengembangan sektor air minum.

8. Kelembagaan Pengelolaan Air Minum Yang Ada Sudah Tidak Memadai Lagi Dengan Perkembangan Saat Ini

Fungsi PDAM sampai saat ini operator penyedia air minum dan sekaligus sebagai pengatur kebijakan air minum didaerah. Disamping itu terdapat ambiguitas misi PDAM, karena ketidakjelasan antara misi sosial dan misi komersial. Sementara itu dalam UU No 7 tahun 2004 (SDA) telah mengamanatkan pembentukan badan pengatur yang bertujuan untuk pengembangan sistem penyediaan air minum dan sanitasi, yang sampai saat ini belum terbentuk.

Didalam UU No 7 tahun 2004 (SDA) diamanatkan bahwa penyelenggaraan pengembangan sistem penyediaan air minum diatur datam Peraturan Pemerintah, saat ini sedang dalam penyusunan.

Dari lebih 300 PDAM yang ada, hanya sebagian kecil (3\%) yang mempunyai pelanggan diatas 100.000 sebagian besar (49\%) PDAM berukuran kecil dengan pelanggan dibawah 10.000 sehingga skala ekonominya kurang atau tidak menguntungkan.

9. Kemitraan Pemerintah dan Swasta Dalam Penyediaan Air Minum Kurang Berkembang

Belum terdapat kesamaan persepsi dan kesepakatan tentang keterlibatan swasta dalam penyediaan air minum, dikalangan pemerintah Kota/Kabupaten. Akibatnya pengelola penyediaan air minum dan atau pemerintah daerah belum siap dalam bermitra dengan swasta. 
Belum terdapat aturan yang cukup mantap dan komprehensip bagi kemitraan pemerintah swasta dalam penyediaan air minum. Proses penyediaan ijin kepada swasta yang berminat jadi penyedia air minum belurn optimal. Sehingga swasta merasa investasi tidak aman dan tidak terjamin pengembaliannya.

Belum terdapat skema pembiayaan yang mendukung keterlibatan swasta datam penyediaan air minum. Umumnya swasta mendapat pembiayaan dari bank dengan bunga komersial, sehingga biaya keuangan yang tinggi mengakibatkan tarif yang tinggi dan membebani petanggan.

Ketentuan pengaturan tarif air minum yang saat ini berlaku, harus mendapat persetujuan oleh DPRD. Ketentuan ini mengakibatkan swasta merasa kepentingannya kurang terlindungi.

10. Kemitraan Permerintah dan Masyarakat Dalam Penyediaan Air Minum Kurang Berkembang Peran serta masyarakat
datam penyelenggaraan
penyediaan air minum masih
terbatas.
masyarakat yang tertibat dan
berkecimpung dalam penyediaan
air minum tidak berkembang.
11. Pemahaman Masyarakat Tentang Air Minum Tidak Mendukung Pengembangan Air Minum

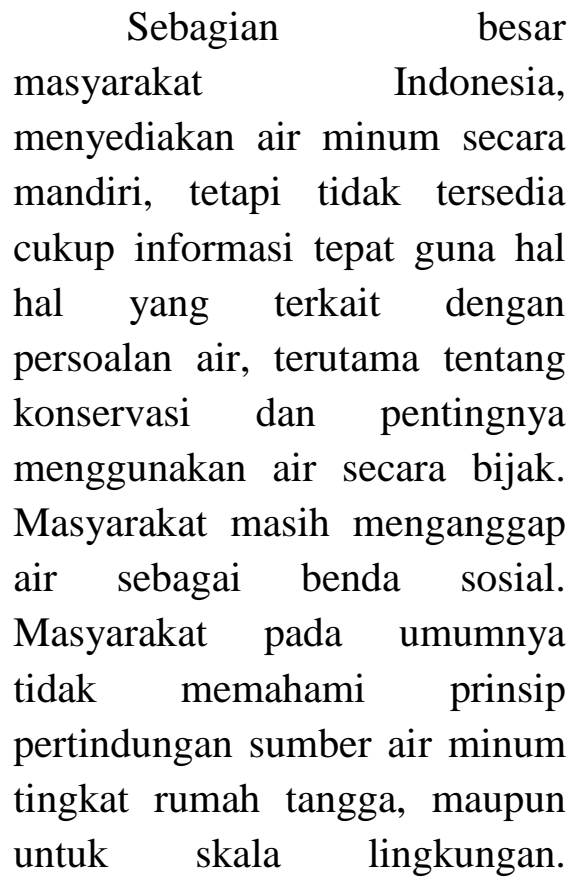
Sedangkan sumber air baku (sungai), difungsikan berbagai macam kegiatan sehari hari, termasuk digunakan untuk mandi, cuci dan pembuangan kotoran/ sampah.

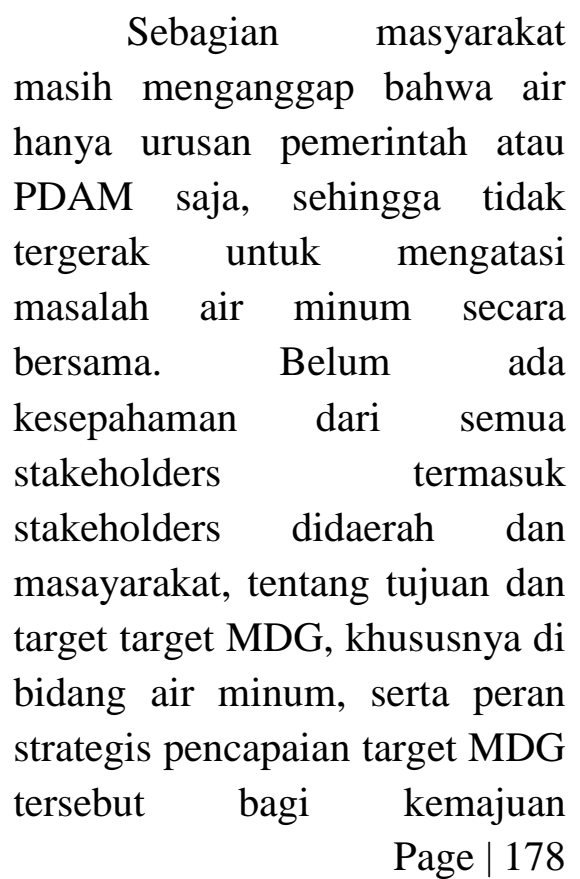


pembangunan air minum di Indonesia.

Keterlibatan perempuan
sebagai pengguna utama dan
pengelota air minum dalam
skala rumah tangga, pada setiap
tahapan pengembangan
penyediaan air minum masih
sangat kurang. Ditingkat
pemerintah pusat telah cukup
banyak program tentang
penyediaan air minum masih
yang dihasilkan, namun kurang
dan tidak tersebar luas pada
tingkat pemerintah daerah
maupun masyarakat di daerah-
daerah terpencil.

\section{KAJIAN TEORI}

\section{Implementasi Kebijakan}

Menurut kamus besar Webster dalam abdul wahab (2008:64) secara singkat merumuskan implementasi yaitu "to implement" (mengimplementasikan) berarti "to provide the means for carryng out" (menyediakan sarana untuk melaksanakan) "to give practical effect to" (menimbulkan dampak/akibat terhadap sesuatu). Sedangkan menurut Mazmanian dan Sabatier dalam Abdul Wahab (2008:65) menjelaskan bahwa impelementasi kebijakan adalah:

"Memahami apa yang senyatanya terjadi sesudah sesuatu progam dinyatakan berlaku atau dirumuskan, merupakan focus perhatian implementasi kebijaksanaan, yakni kejadian-kejadian dan kegiatan-kegiatan yang timbul sesudah disahkan pedoman kebijaksanaan Negara yang mencakup baik usaha-usaha untuk mengadministrasikannya maupun untuk menimbulkan akibat/dampak nyata bagi masyarakat atau kejadian".

Dalam implementasi kebijakan terdapat tiga model yang berkembang dan akhirnya seringkali digunakan dalam pola pelaksanaan kebijakan. Seperti yang dikemukakan Abdul Wahab (2008:71-109), model-model tersebut antara lain:

a) "Model "the top down approach" yang dikembangkan oleh Brian W. Hogwood dan Lewis A. Gunn. Model ini lebih menekankan pada kebijaksanaan para aktor pelaksana dan kondisi yang mungkin terjadi di lapangan, sehingga dalam pelaksanaannya kemungkinan-kemungkinan yang akan terjadi telah dipersiapkan sedemikian rupa, sehingga pelaksanaan kegiatan program berjalan dengan baik sesuai dengan yang diharapkan. 
b) Model proses implementasi kebijakan yang dikembangkan oleh Van Meter dan Van Horn. Dengan model ini, implementasi kebijakan dipandang sebagai prosedur-prosedur yang meliputi konsep-konsep seperti: perubahan, kontrol dan kepatuhan bertindak.

c) Model kerangka analisis implementasi yang dikembangkan oleh Daniel Mazmanian dan Paul A. Sebatier.

\section{Pemberdayaan Masyarakat}

$\begin{array}{cr}\text { Pemberdayaan } & \text { yang } \\ \text { diadaptasikan dari istilah }\end{array}$ empowerment berkembang di Eropa mulai abad pertengahan, terus berkembang hingga diakhir 70-an, 80-an, dan awal 90-an. Konsep pemberdayaan tersebut kemudian mempengaruhi teori-teori yang berkembang belakangan. Jika dilihat dari proses operasionalisasinya, maka ide pemberdayaan memiliki dua kecenderungan, antara lain: pertama, kecenderungan primer, yaitu kecenderungan proses yang memberikan atau mengalihkan sebagian kekuasaan, kekuatan, atau kemampuan (power) kepada masyarakat atau individu menjadi lebih berdaya.

Proses yang pertama ini dapat dilengkapi pula dengan upaya membangun asset material guna mendukung pembangunan kemandirian mereka melalui organisasi; dan kedua, kecenderungan sekunder, yaitu kecenderungan yang menekankan pada proses memberikan stimulasi, mendorong atau memotivasi individu agar mempunyai kemampuan atau keberdayaan untuk menentukan apa yang menjadi pilihan hidupnya melalui proses dialog. Dua kecenderungan tersebut memberikan (pada titik ekstrem) seolah berseberangan, namun seringkali untuk mewujudkan kecenderungan primer harus melalui kecenderungan sekunder terlebih dahulu.

Beberapa pandangan tentang pemberdayaan masyarakat, antara lain sebagai berikut : (Ife, 1996:59 dalam Chandra :

1. Struktural, pemberdayaan merupakan upaya pembebasan, transformasi struktural secara fundamental, dan eliminasi struktural atau sistem yang operesif.

2. Pluralis, pemberdayaan sebagai upaya meningkatkan daya sesorang atau sekelompok orang untuk dapat bersaing dengan kelompok lain dalam suatu 'rule of the game' tertentu.

3. Elitis, pemberdayaan sebagai upaya mempengaruhi elit, membentuk aliniasi dengan elit-elit tersebut, serta berusaha melakukan perubahan terhadap 
praktek-praktek dan struktur yang elitis.

\section{Post-Strukturalis,}

pemberdayaan merupakan upaya mengubah diskursus serta menghargai subyektivitas dalam pemahaman realitas sosial.

\section{Pembangunan Kesehatan}

Pembangunan kesehatan merupakan salah satu upaya yang dilakukan secara sadar dan berkesinambungan, terencana oleh pemerintah melalui programprogram nasional yang bergerak di bidang kesehatan. Dalam menunjang berbagai program pembagunan kesehatan di Indonesia, Depkes akan menempuh 4 strategi utama, yaitu:

1. Menggerakkan dan masyarakat untuk hidup sehat. Sasaran utama strategi ini adalah seluruh desa menjadi desa siaga, seluruh masyarakat berperilaku hidup bersih dan sehat serta seluruh keluarga sadar gizi.

2. Meningkatkan akses masyarakat tehadap pelayanan kesehatan yang berkualitas. Sasaran utama strategi ini adalah setiap orang miskin mendapatkan pelayanan kesehatan yang bermutu; setipa bayi, anak, dan kelompok masyarakat risiko tinggi terlindungi dari penyakit; di setiap desa tersedia SDM kesehatan yang kompeten; di setiap desa tersedia cukup obat esensial dan alat kesehatan dasar; setiap Puskesmas dan jaringannya dapat menjangkau dan dijangkau seluruh masyarakat di wilayah kerjanya; pelayanan kesehatan di setiap rumah sakit, Puskesmas dan jaringannya memenuhi standar mutu.

3. Meningkatkan sistem surveillans, monitoring dan informasi kesehatan. Sasaran utama dari strategi ini adalah: setiap kejadian penyakit terlaporkan secara cepat kepada desa/lurah untuk kemudian diteruskan ke instansi kesehatan terdekat; setiap kejadian luar biasa (KLB) dan wabah penyakit tertanggulangi secara cepat dan tepat sehingga tidak menimbulkan dampak kesehatan masyarakat; semua ketersediaan farmasi, makanan dan perbekalan kesehatan memenuhi syarat; terkendalinya pencemaran lingkungan sesuai dengan standar kesehatan; dan berfungsinya sistem informasi kesehatan yang evidence based di seluruh Indonesia.

4. Meningkatkan pembiayaan kesehatan. Sasaran utama dari strategi ini adalah: pembangunan kesehatan memperoleh prioritas Page | 181 


$\begin{array}{lr}\text { penganggaran } & \text { pemerintah } \\ \text { pusat dan daerah; anggaran } \\ \text { kesehatan } & \text { pemerintah } \\ \text { diutamakan untuk upaya } & \text { upana } \\ \text { pencegahan dan } & \text { promosi } \\ \text { kesehatan; dan terciptanya } \\ \text { sistem jaminan pembiayaan } \\ \text { kesehatan terutama bagi rakyat } \\ \text { miskin. }\end{array}$

5. Pelaksanaan pembangunan kesehatan, departemen kesehatan bertekad menjunjung tinggi nilai-nilai sebagai berikut:

a. Berpihak Pada Rakyat

Dalam proses penyelenggaraan pembangunan kesehatan, Departemen Kesehatan akan selalu berpihak pada rakyat. Diperolehnya derajat kesehatan yang setinggitingginya bagi setiap orang adalah salah satu hak asasi manusia tanpa membedakan suku, golongan agama, dan status sosial ekonomi.

b. Bertindak Cepat dan Tepat

$\begin{array}{lr}\text { Dalam } & \text { mengatasi } \\ \text { masalah } & \text { kesehatan, } \\ \text { apalagi yang } & \text { bersifat } \\ \text { darurat harus } & \text { dilakukan } \\ \text { secara cepat. } & \text { Tindakan } \\ \text { yang cepat juga harus } \\ \text { diikuti }\end{array}$

pertimbangan yang cermat, sehingga dapat mengenai sasaran dengan intervensi yang tepat.

c. Kerjasama Tim

Dalam mengemban tugas pembangunan kesehatan, harus dibina kerja tim yang utuh dan kompak, dengan menerapkan prinsip koordinasi, integrasi, sinkronisasi dan sinergisme.

d. Integritas Tinggi

Dalam melakasanakan tugas, semua anggota Departemen Kesehatan harus memiliki ketulusan hati, kejujuran, berkepribadian yang teguh, dan bermroral tinggi.

e. Transparan dan Akuntabilitas

Semua kegiatan pembangunan kesehatan yang diselenggarakaan oleh Departemen Kesehatan, harus dilaksanakan secara transparan dan dapat dipertanggungjawabkan kepada publik. (www.kemenkes.go.id) 


\section{PEMBAHASAN}

\section{Kebijakan PAMSIMAS}

PAMSIMAS merupakan
singkatan dari Penyediaan Air
Minum dan Sanitasi Berbasis
Masyarakat. Program PAMSIMAS
ini merupakan kelanjutan dari
program sebelumnya yakni program
WSSLIC (Water Supply and
Sanitation for Low Income Community). Program PAMSIMAS ini merupakan program pemerintah yang bergerak di bidang air minum dan sanitasi masyarakat. Program PAMSIMAS yang diluncurkan oleh pemerintah Indonesia ini didasarkan pada fakta masih minimnya akses air minum dan sarana sanitasi yang memadai di Indonesia yang berdampak pada kondisi sanitasi yang buruk dan meningkatnya penyakit berbasis lingkungan.

Tujuan Umum Program PAMSIMAS untuk:

1. Meningkatkan jumlah warga misikin pedesaan dan pinggiran kota (peri urban) yang dapat mengakses perbaikan pelayanan serta fasilitas air minum dan sanitasi.

2. Meningkatkan nilai dan perilaku hidup bersih dan sehat (PHBS) dalam rangka usaha pencapaian target MDG sector air minum dan sanitasi melalui upaya-upaya pengarusutamakan (mainstreaming).

\section{Perluasan (scaling-up) pendekatan berbasis masyarakat (community driven approach). \\ (www.pamsimas.or.id)}

Secara khusus kegiatan Promosi Kesehatan dan Sanitasi dalam Pamsimas bertujuan untuk menurunkan angka penyakit berbasis air dan lingkungan melalui peningkatan kapasitas dan kemampuan masyarakat untuk merencanakan dan melaksanakan program pengembangan cakupan sanitasi melalui pengembangan jamban keluarga dan pembangunan sarana sanitasi di masyarakat, dan sekolah, melalui pengembangan SAB/S dan Program PHBS.

Tujuan Khusus Program PAMSIMAS untuk:

1. Meningkatkan komunikasi atau interaksi antara individu dan kelompok dalam masyarakat (laki-laki, perempuan, kaya, miskin) secara partisipatif, yang di kelola oleh masyarakat untuk mengubah perilaku buruk yang berkaitan dengan perilaku kunci PHBS yang mempunyai daya ungkit terhadap pencegahan penyakit penyakit yang di tularkan melalui air dan lingkungan.

2. Meningkatkan kapasitas masyarakat dan kapasitas kelembagaan khususnya 
kelembagaan di masyarakat dalam pengelolaan air bersih, promosi kesehatan dan sanitasi secara terpadu dan berkesinambungan.

3. Meningkatnya fasilitasi masyarakat secara partisipatif menggunakan metode partisipatif yang dilaksanakan sesuai dengan potensi dan kondisi setempat.

4. Meningkatnya promosi kesehatan dan sanitasi secara partisipatif dan terintegrasi dengan program yang terkait melalui institusi lain seperti sekolah

5. Meningkatkannya promosi kesehatan melalui berbagai saluran komunikasi untuk mendukung pelaksanaan promosi kesehatan dan sanitasi yang dilaksanakan secara partisipatif oleh masyarakat.

(www.pamsimas.or.id)

Sasaran Program Pamsimas merupakan program berbasis masyarakat. Untuk menimbulkan masyarakat yang mandiri perlu didampingi oleh fasilitator masyarakat, khususnya fasilitator kesehatan. Sehubungan hal tersebut, maka buku pedoman ini sebagai acuan bagi Fasilitator Kesehatan, atau pihak-pihak lain, yang akan mendampingi masyarakat dalam mewujudkan kesehatan masyarakat secara mandiri, melalui pengenalan diri, perencanaan, pelaksanaan dan monitoring serta evaluasinya.

Adapun ruang lingkup kegiatan program PAMSIMAS ini terdiri dari beberapa komponen antara lain: Pemberdayaan masyarakat dan pengembangan kelembagaan lokal, Peningkatan kesehatan dan perilaku hidup bersih dan sehat serta pelayanan sanitasi, Penyediaan sarana air minum dan sanitasi umum di tingkat desa, kelurahan, kabupaten /kota.

Stakeholder dan Pendanaan dalam PAMSIMAS sendiri ditopang oleh kerjasama lintas sektor yang melibatkan Badan Perencanaan Pembangunan Nasional, Kementerian Pekerjaan Umum, Kementerian Kesehatan, Kementerian Dalam Negeri, Kementerian Keuangan dan didukung oleh Bank Dunia. Dalam implementasinya, PAMSIMAS didukung oleh LSM, masyarakat, dan pejabat daerah setempat (pemprov, pemkab, kecamatan, kelurahan, RT, RW).

Sementara itu, pendanaan program PAMSIMAS berasal dari sumber dana kredit IDA (International Development Association), rupiah murni (Anggaran Pendapatan dan Belanja Negara, Anggaran Pendapatan dan Belanja Daerah Propinsi, Anggaran Pendapatan dan Belanja Daerah Kabupaten/Kota serta dana kontribusi swadaya masyarakat). 
Alokasi dana Kredit IDA pada dasarnya terbagi atas 2 bagian yaitu :

1. Alokasi Bantuan Langsung Masyarakat

Desa/kelurahan, bantuan dana yang diberikan langsung kepada masyarakat untuk membiayai kegiatan Pamsimas pada sarana air minum dan kesehatan masyarakat yang dituangkan dalam Rencana Kerja Masyarakat (RKM), dan

2. Alokasi Non BLM, bantuan dana diluar BLM untuk menunjang pelaksanaan kegiatan di tingkat pusat, provinsi, kabupaten, kecamatan dan desa. Dana ini meliputi pengadaan barang, lokakarya dan pelatihan komponen 1, 2 dan 5, Jasa Konsultan dan lain sebagainya. Sedangkan dana Rupiah murni dibagi menjadi:

a. APBN

Dana yang berasal dari pemerintah pusat antara lain digunakan untuk sebagian kegiatan yang berkaitan dengan

1. Manajemen proyek,

2. Pelatihan,

3. Honorarium,

4. Perjalanan,

5. Monitoring,

6. Operasional kantor dan sarana kerja lainnya baik di pusat maupun di daerah, dll.

Kegiatan yang sebagian akan dibiayai dari APBN adalah:

1. Pengadaan barang barang,

2. Pengadaan jasa konsultan,

3. Biaya operasional tingkat pusat, dll.

b. APBD Provinsi

Dana yang berasal dari Pemerintah Provinsi yang dianggarkan tiap tahunnya adalah kegiatan proyek untuk pos-pos yang telah ditetapkan oleh Biro Keuangan dan Bappeda dari Pemerintah Provinsi Peserta Pamsimas, antara lain :

1. pelatihan,

2. honorarium,

3. perjalanan di tingkat provinsi sampai ke daerah dan pusat,

4. Manajemen dan operasional kantor PPMU, dll.

c. APBD Kabupaten/kota

Dana yang berasal dari Pemerintah Kabupaten/ kota dianggarkan tiap tahunnya untuk kegiatan proyek termasuk kegiatan 
yang tidak dibiayai atau sebagian dibiayai melalui dana Bank Dunia tetapi sudah disepakati pada saat negosiasi. Kegiatan tersebut, antara lain :

1. Manajemen proyek,

2. Pelatihan,

3. Honorarium, perjalanan,

4. Monitoring, operasional kantor dan sarana kerja lainnya baik di kabupaten/ kota sampai tingkat desa,

d. Kontribusi Masyarakat

Kontribusi masyarakat dalam program

PAMSIMAS ini minimal sebesar $20 \%$ dari total dana sub-proyek.

Adanya kontribusi masyarakat dalam bentuk kredit atau cash tersebut diharapkan dapat memicu kesadaran masyarakat dan juga sebagai wujud dari komitmen membangun 'sense of belonging' dan 'sense of responsibility' terhadap kegiatan maupun hasil yang dicapai oleh masyarakat sendiri.

\section{Fakta Pendukung}

PAMSIMAS merupakan salah satu program pembangunan di bidang kesehatan yang tepat mengatasi permasalahan air bersih di Indonesia. Hal ini sejalan dengan fakta yang dinyatakan oleh kementrian lingkungan hidup, yaitu Indonesia pernah berada pada urutan ke lima sebagai negara kaya air di dunia dengan 2.779 milimeter rata2 curah hujan pertahun. Namun $66 \%$ dari air hujan itu berubah menjadi air melimpah yang bisa menimbulkan bencana banjir dan tanah longsor akibat tidak terserap tanah yang sudah gundul dan akibat perusakan hutan terus menerus. Pada tahun 2006 setidaknya 90 juta rakyat Indonesia tidak memiliki akses ke air bersih. Belum lagi diperparah dengan perubahan musim yang menyebabkan timbulnya kekeringan (Kementerian Lingkungan Hidup RI, www.kemenlh.go.id)

UNICEF memperkirakan, bahwa saat ini terdapat 1.6 juta anak meninggal karena tidak mendapat akses untuk air bersih. Dengan penyediaan air bersih saja dan perbaikan sanitasi, kita dapat menurunkan, angka kemiskinan, angka kesakitan, dan meningkatkan pendidikan anak-anak kita. Demikian halnya dengan masalah cacingan pada anak-anak. Saat ini puluhan juta, bahkan ratusan juta anak menderita cacingan karena masalah air bersih, sanitasi dan perumahan yang buruk. Akibatnya mereka menderita kekurangan gizi, yang berdampak pada kesehatan dan pendidikan mereka. (www.unicef.or) 
Berita dari Indonesia Today headline news, edisi Sabtu 30 April 2010: Demak-Program PAMSIMAS (Penyediaan Air Minum Dan Sanitasi Berbasis Masyarakat) yang digulirkan Pemerintah beberapa tahun ini cukup bermanfaat bagi warga pedesaan dalam rangka penyediaan air bersih. Dulu sebelum adanya program ini masyarakat kesulitan memperoleh air bersih, sehingga mereka menggunakan air sungai, blumbang, saluran untuk kebutuhan MCK. Akibatnya mereka banyak yang terserang berbagai penyakit karena kurang higienisnya air tersebut. Namun setelah adanya program PAMSIMAS pola hidup

PAMSIMAS mejadi salah satu program nasional yang fokus membantu penyelesaian masalah air dan sanitasi di Indonesia. PAMSIMAS menjadi agenda pembangunan nasional di bidang kesehatan yang menjadi bagian dari Sistem Penyediaan Air Minum (SPAM) pedesaan. PAMSIMAS ini sebernarnya telah berjalan sejak tahun 2006, dan program ini merupakan satu rangkaian pembangunan pro masyarakat yang dikemas dalam SPAM.

Lingkup pekerjaan yang dilakukan meliputi Pemberdayaan kemampuan

Pengembangan/ Masyarakat, Kelembagaan Lokal, Peningkatan Kesehatan Perilaku Hidup Bersih dan Sehat, Layanan Sanitasi dan Penyediaan Sarana Air Minum, pada sehat warga masyarakat makin kentara karena mereka sekarang tidak lagi menggunakan air sungai yang kotor. Dengan adanya PAMSIMAS di desa kami jelas ada perubahan sikap masyarakat dalam hal hidup sehat, karena setelah rumah mereka terairi maka kebutuhan MCK mereka tidak lagi ke sungai atau kolam namun semuanya dilakukan di rumah. Adanya PAMSIMAS ini benar-benar dirasakan oleh warga desa Jungpasir ini, " ujar M. Abdullah Afif (43) ketua BPS (Badan Pengelola Sarana) PAMSIMAS "AJAIB" desa Jungpasir pada Fatkhul Muin. (www.indonesiatoday.co.id)

masing-masing desa sasaran, sebagaimana budaya dan kearifan lokal sesuai alokasi penempatan yang telah ditetapkan untuk wilayah kabupaten Parigi Moutong yang diperuntukan bagi masyarakat miskin dengan akses terhadap Air Bersih/Minum dan Sanitasi yang rendah serta lingkungan Masyarakat Sekolah, khususnya Sekolah Dasar dengan skala prioritas kebutuhan sesuai batasan ketentuan program PAMSIMAS.

Prioritas

Kesehatan PAMSIMAS adalah untuk mencegah terjadinya penularan penyakit berbasis air dan lingkungan, dilakukan dengan dua kegiatan pokok yaitu :

a. Perubahan perilaku buruk yang masih terjadi di masyarakat 
menjadi perilaku hidup bersih dan sehat (PHBS) tentang :

1. Stop buang air besar sembarangan

2. Cuci tangan pakai sabun.

3. Mengelola air minum dan makanan yang aman.

4. Mengelola sampah dengan benar.
5. Mengelola limbah cair rumah tangga dengan aman

b. Pembangunan sarana :

1. Pembangunan jamban keluarga.

2. Pembangunan sarana air bersih.

\section{GAMBAR 2. SKEMA SPAM DAN PAMSIMAS}

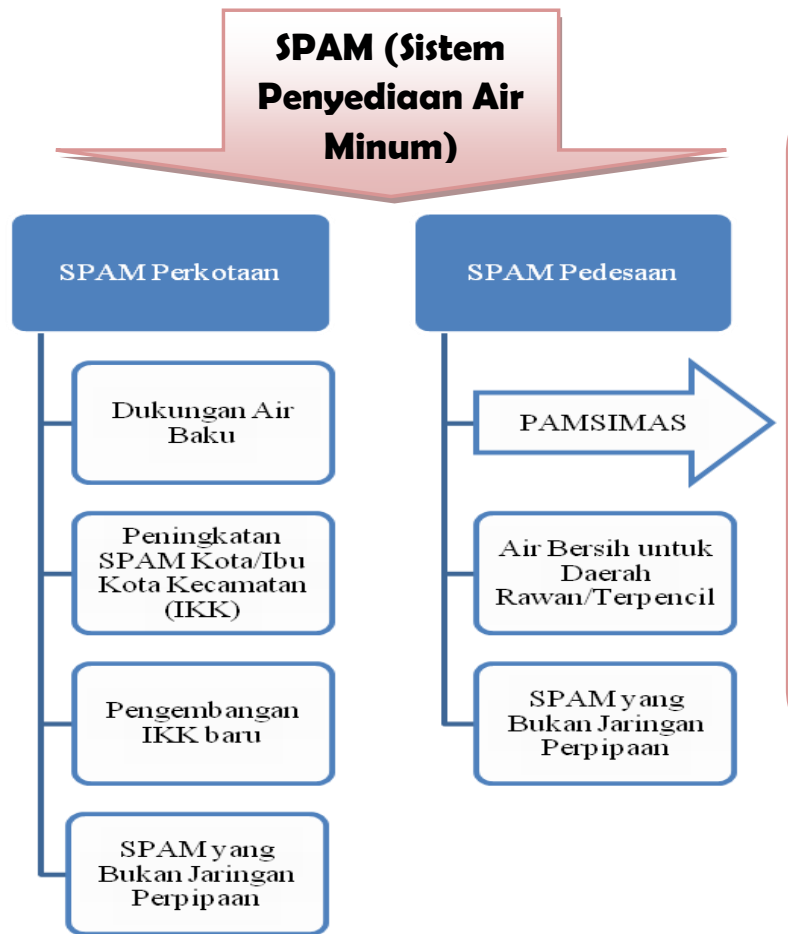

STBM (Sanitasi Total Berasis Masyarakat)

$>$ Stop Buang Air Besar Sembarangan (Stop BABS)

$>$ Cuci Tangan Pakai Sabun (CTPS)

$>$ Pengelolaan Air Minum di Rumah Tangga (PAM RT)

$>$ Pengelolaan Sampah Rumah Tangga

$>$ Pengelolaan Limbah Cair Rumah Tangga
Masih cukup banyak masyarakat Indonesia entah itu yang tinggal di daerah perkotaan maupun yang tinggal di pedesaan yang masih berkutat dengan persoalan air minum dan sanitasi. Karena itu pemerintah Indonesia merasa perlu mengatasi masalah seperti ini, salah satunya melalui program PAMSIMAS ini. Melalui program PAMSIMAS ini, pemerintah Indonesia bertekad untuk mencapai target Water Supply and Sanitation- Millenium Development Goals (WSS-MDGs), yaitu menurunnya jumlah penduduk yang belum memiliki akses air minum dan sanitasi dasar sebesar $50 \%$ pada tahun 2015. 


\section{Model Implementasi Kebijakan PAMSIMAS}

Model implementasi kebijakan PAMSIMAS ini adalah model implementasi bottom up. Dimana kebijakan diambil berdasarkan aspirasi dari masyarakat baik secara langsung maupun melalui lembaga-lembaga kemasyarakatan. Hal ini dapat dibuktikan di dalam forum PAMSIMAS masyarakat secara leluasa diberikan kebebasan untuk mengutarakan keinginannya yang kemudian dikoordinasikan dengan tim PAMSIMAS yang lain.

1. Pemberdayaan Masyarakat dalam PAMSIMAS

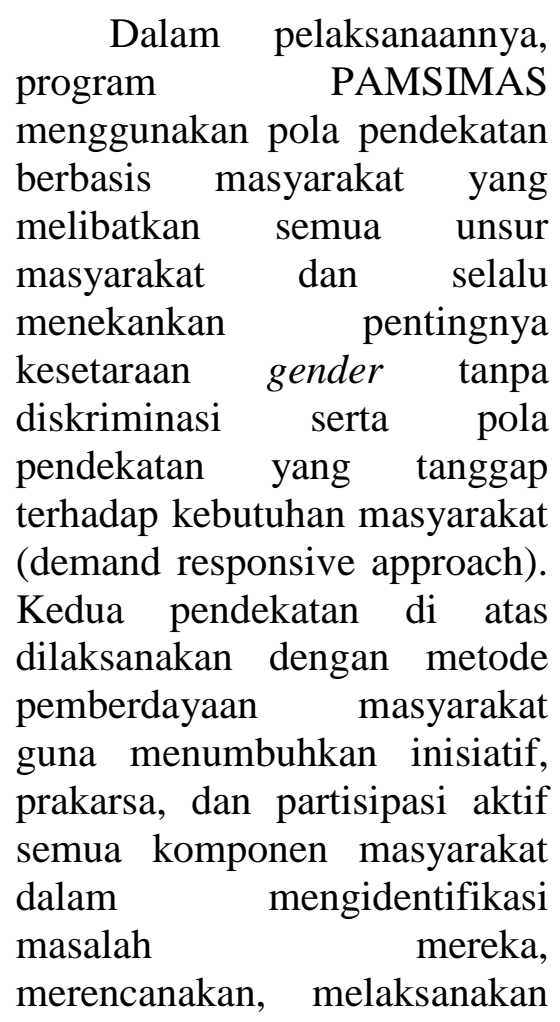

dan mengoperasionalkan dan menjaga sarana yang sudah dibangun.

Selama kegiatan program PAMSIMAS, masyarakat didampingi oleh beberapa tenaga fasilitator yang terdiri dari: fasilitator kelembagaan, fasilitator kesehatan dan fasilitator teknik. Dengan adanya dukungan kontribusi masyarakat, maka akan munculnya kesadaran dan rasa memiliki masyarakat dan tanggung jawab terhadap pelaksanaan dan hasil kegiatan PAMSIMAS, sehingga dana bantuan program PAMSIMAS hanya merupakan stimulant dan reward terhadap masyarakat atas lahirnya prakarsa, inisiatif, kepedulian dan tanggung jawab masyarakat.

2. Implementasi Kebijakan Program PAMSIMAS di Jawa Tengah

Program PAMSIMAS (Penyediaan Air Minum Dan Sanitasi Berbasis Masyarakat) yang digulirkan pemerintah beberapa tahun ini, cukup bermanfaat bagi warga pedesaan dalam rangka peyediaan air bersih. Contohnya Pamsimas Kab Pekalongan, Jawa Tengah yang meraih prestasi PAMSIMAS Terbaik Tingkat Provinsi dan Nasional tahun 2010 lalu. 


\section{Gambar 3. Pipa Air}
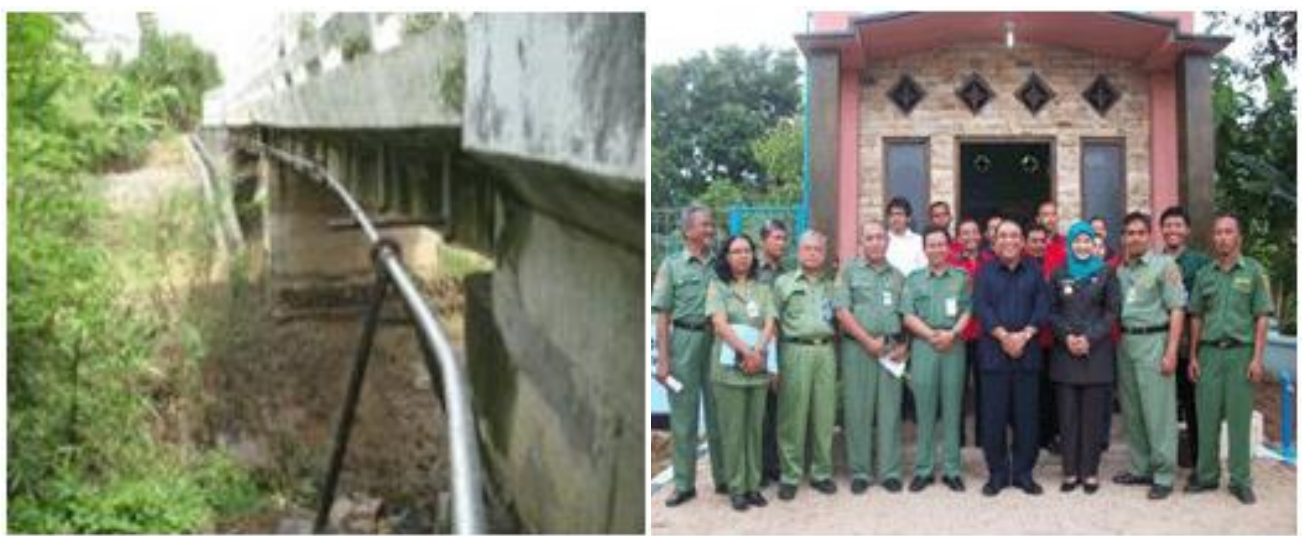

Meraih Penghargaa

Predikat terbaik yang telah diberikan oleh Pemerintah Pusat maupun Provinsi kepada Kabupaten Pekalongan didasarkan pada penilaian lebih dalam pelaksanaan PAMSIMAS. Keberhasilan Pemerintah Kabupaten Pekalongan menjadi terbaik di Jawa Tengah dan tingkat nasional dalam merencanakan, melaksanakan dan memelihara program PAMSIMAS tidak lepas dari komitmen Kepala Daerah beserta jajarannya dan dukungan masyarakat desa yang mendapatkan program tersebut. Prestasi ini juga didasarkan pada penilaian lebih dalam pelaksanaan PAMSIMAS, yaitu respon pemerintah daerah yang bagus melalui sharing pendanaan dari APBD maupun serapan swadaya masyarakat yang lebih bagus dibanding daerah-daerah lain di Indonesia.

\section{Partisipasi APBD}

Kabupaten Pekalongan dan serapan swadaya masyarakat dalam melaksanakan program
PAMSIMAS tersebut dari segi jumlah adalah yang tertinggi se-Indonesia. Dari sisi pelaksanaan juga telah dinilai dapat menyelesaikan program tepat waktu (tercepat dalam pelaksanaan), sedangkan dari sisi manajemen pengendalian pelaksanaan program dapat dilaksanakan dengan baik sehingga mencapai sasaran sebagaimana diharapkan pemerintah, bahkan dapat dikembangkan lebih lanjut oleh masyarakat.

Dalam pelaksanaanya, program PAMSIMAS di Pekalongan Jawa Tengah ditentukan oleh berbagai faktor, yaitu:

1. Dukungan dari berbagai instansi terkait yang turut mensukseskan pelaksanaan PAMSIMAS di kabupaten Pekalongan. Adanya koordinasi Bidang Cipta Karya DPU Kab. Pekalongan selaku DPMU (District Project Management Unit) ke PPMU (Provincial Project Management Unit) Cipta 
Karya PU Provinsi Jateng setiap 3 bulan sekali melaksanakan paparan di Provinsi, demikian pula menjalin komunikasi dan koordinasi dengan CPMU di Ditjen Cipta Karya Departemen PU RI dan konsultan program.

2. Di tingkat Kabupaten, setiap seminggu sekali (setiap Senin) diadakan pertemuan dengan para fasilitator untuk membahas dan mengevaluasi kemajuan program maupun kendala yang dihadapi di lapangan, dan bila ditemukan permasalahan dapat segera diambil langkah tindak penyelesaiannya dengan bekerja bersama masyarakat secara langsung.

3. Indikator keberhasilan program PAMSIMAS di Kabupaten Pekalongan ini ditentukan oleh tingginya partisipasi masyarakat sejak proses perencanaan, pengelolaan pelaksanaan program hingga pelaporan maupun pengendalian kegiatan.

\section{a. Implementasi Kebijakan Program PAMSIMAS di Papua Barat}

Implementasi program PAMSIMAS di Papua Barat kurang memberikan hasil yang kentara. Padahal, sumber air datang dari gunung dan sungai, bersih dan belum tercemar polusi. Namun sayangnya, air itu tidak bisa terakses ke kampung dan perumahan penduduk. Ia sangat berharap program PAMSIMAS itu dapat membuat air bersih mengalir ke rumah-rumah penduduk. Unsur pemberdayaan dalam PAMSIMAS kurang terlihat implementasinya.

\section{b. Hambatan Implementasi PAMSIMAS di Papua Barat}

\section{Rendahnya nilai kesadaran masyarakat dalam kegiatan pembangunan, seperti dalam table berikut :}


Table 1. Angka Partisipasi Sekolah (APS) menurut Kabupaten/Kota dan Kelompok Umur tahun 2008 - 2009

\begin{tabular}{|c|c|c|c|c|}
\hline \multirow{2}{*}{$\begin{array}{c}\text { Kabupaten/Kota } \\
\text { Regency/Municipality }\end{array}$} & \multicolumn{4}{|c|}{ Kelompok Umur/ Age Groups (dalam \%) } \\
\hline & $7-12$ & $13-15$ & 16 - 18 & $19-24$ \\
\hline$(1)$ & $(2)$ & (3) & (4) & (5) \\
\hline \multicolumn{5}{|l|}{ Kabupaten/Regency } \\
\hline 01. Fakfak & 93,65 & 87,97 & 53,02 & 16,8 \\
\hline 02. Kaimana & 97,20 & 82,31 & 39,03 & 10,03 \\
\hline 03. Teluk Wondama & 89,07 & 91,35 & 62,31 & 10,32 \\
\hline 04. Teluk Bintuni & 96,12 & 81,18 & 56,94 & 5,42 \\
\hline 05. Manokwari & 91,24 & 89,79 & 79,15 & 17,68 \\
\hline 06. Sorong Selatan & 90,78 & 71,09 & 41,83 & 17,85 \\
\hline 07. Sorong & 88,79 & 86,36 & 53,62 & 6,8 \\
\hline 08. Raja Ampat & 94,34 & 95,17 & 61,76 & 14,09 \\
\hline \multicolumn{5}{|l|}{ Kota/Municipality } \\
\hline 71. Sorong & 98,26 & 96,81 & 45,93 & 10,16 \\
\hline Papua Barat 2009 & 93,35 & 88,59 & 57,95 & 12,72 \\
\hline
\end{tabular}

Sumber: BPS Provinsi Papua Barat ( 2009)

2. Kondisi geografis memberikan permasalahan dan hambatan tersendiri bagi implementasi PAMSIMAS

1. Kondisi alam Provinsi Papua Barat yang merupakan wilayah daratan yang bergununggunung, dan ada juga yang tandus.

2. Kualitas sumberdaya air yang belum termanfaatkan dengan baik serta adanya beberapa kawasan yang rawan bencana dapat menjadi kendala dalam pengembangan wilayah.

3. Akses antar kabupaten masih bertumpu pada angkutan laut dan udara, dan pelayanan angkutan darat yang masih perlu ditingkatkan.

4. Adanya kesenjangan ekonomi antara pusat pertumbuhan dengan daerah-daerah

belakangnya dan kawasan-kawasan pulaupulau kecil yang relatif masih terbelakang (khususnya yang masih sulit dijangkau). 
3. Tingkat pendidikan yang masih rendah mempengaruhi pola pikir dan keaktifan masyarakat dalam pembagunan

Tabel 2. Daftar tingkat pendidikan Papua Barat Tahun 2009

\begin{tabular}{|c|c|c|c|c|c|c|c|c|c|}
\hline \multirow[b]{2}{*}{ Kab. } & \multirow{2}{*}{$\begin{array}{c}\text { Tdk/Blm } \\
\text { pernah } \\
\text { Sekolah }\end{array}$} & \multirow{2}{*}{$\begin{array}{c}\text { Tidak } \\
\text { Tamat } \\
\text { SD }\end{array}$} & \multirow[b]{2}{*}{ SD } & \multirow[b]{2}{*}{ SLTP } & \multirow[b]{2}{*}{ SLTA } & \multirow{2}{*}{$\begin{array}{c}\text { SLTA } \\
\text { Kejuruan }\end{array}$} & \multicolumn{2}{|c|}{ Akademi } & \multirow[b]{2}{*}{ Univ } \\
\hline & & & & & & & D1/D2 & D3 & \\
\hline Fakfak & 0,87 & 13,87 & 38,73 & 22,40 & 27,05 & 4,34 & 0,29 & 0,14 & 2,31 \\
\hline Kaimana & 5,03 & 20,55 & 37,32 & 24,11 & 7,55 & 3,56 & 0,00 & 0,63 & 1,26 \\
\hline $\begin{array}{c}\text { Teluk } \\
\text { Wondama }\end{array}$ & 4,86 & 24,32 & 49,73 & 12,97 & 5,41 & 1,62 & 0,54 & 0,54 & 0,00 \\
\hline $\begin{array}{l}\text { Teluk } \\
\text { Bintuni }\end{array}$ & 17,11 & 17,94 & 37,94 & 20,00 & 4,95 & 2,06 & 0,00 & 0,00 & 0,00 \\
\hline Manokwari & 9,26 & 21,91 & 36,49 & 16,25 & 9,26 & 3,83 & 0,72 & 0,44 & 1,83 \\
\hline $\begin{array}{l}\text { Sorong } \\
\text { Selatan }\end{array}$ & 11,20 & 22,41 & 43,15 & 13,28 & 7,05 & 1,66 & 0,83 & 0,00 & 0,41 \\
\hline Sorong & 3,04 & 30,91 & 46,50 & 13,08 & 3,04 & 2,25 & 0,26 & 0,26 & 0,66 \\
\hline Raja Ampat & 9,42 & 24,61 & 49,21 & 12,04 & 3,66 & 0,00 & 0,00 & 0,00 & 0,00 \\
\hline Kota Sorong & 0,59 & 10,54 & 19,31 & 22,18 & 28,16 & 12,06 & 1,26 & 1,77 & 4,13 \\
\hline
\end{tabular}

Sumber: BPS Provinsi Papua Barat (Diolah dari hasil Survei Sosial Ekonomi Nasional

\section{Kurangnya komitmen pemerintah terhadap program}

Meski pemerintah pusat mengatakan bahwa PAMSIMAS akan dilakukan merata di wilayah Indonesia, khususnya yang kekurangan akses air bersih, pada kenyataannya PAMSIMAS hanya terfokus di ibu kota provinsi Papua Barat, yaitu di Manowari. Situasi ini mengesankan kurangnya komitmen pemerintah untuk mencanangkan perluasan program di penjuru tanah air.

\section{c. Perbandingan Keberhasilan Implementasi Kebijakan Program PAMSIMAS di Berbagai Provinsi di Indonesia}

Tingkat keberhasilan program PAMSIMAS disajikan dalam table berikut ini : 
Tabel 3. Perbandingan keberhasilan implementasi PAMSIMAS di Indonesia

\begin{tabular}{|c|c|c|c|c|c|c|c|c|}
\hline $\begin{array}{l}\mathbf{N} \\
\mathbf{o}\end{array}$ & Provinsi & $\begin{array}{l}\text { Kab / } \\
\text { Kota }\end{array}$ & $\begin{array}{l}\text { Desa } \\
2008\end{array}$ & $\begin{array}{c}\text { Status } \\
2008\end{array}$ & $\begin{array}{l}\text { Desa } \\
2009\end{array}$ & $\begin{array}{c}\text { Status } \\
2009\end{array}$ & $\begin{array}{l}\text { Desa } \\
2010\end{array}$ & $\begin{array}{c}\text { Status } \\
2010\end{array}$ \\
\hline 1 & Sumatera Barat & 13 & 100 & 100 & 178 & 178 & 195 & 171 \\
\hline 2 & Riau & 6 & 50 & 50 & 84 & 84 & 90 & 84 \\
\hline 3 & Sumatera Selatan & 8 & 31 & 31 & 127 & 111 & 107 & 75 \\
\hline 4 & Banten & 2 & 18 & 18 & 30 & 30 & 26 & 26 \\
\hline 5 & Jawa Barat & 5 & 45 & 45 & 74 & 74 & 75 & 75 \\
\hline 6 & Jawa Tengah & 30 & 270 & 270 & 446 & 446 & 399 & 334 \\
\hline 7 & $\begin{array}{l}\text { Kalimantan } \\
\text { Selatan }\end{array}$ & 8 & 71 & 65 & 119 & 108 & 108 & 50 \\
\hline 8 & $\begin{array}{l}\text { Nusa Tenggara } \\
\text { Timur }\end{array}$ & 11 & 97 & 70 & 162 & 142 & 155 & 0 \\
\hline 9 & Sulawesi Barat & 3 & 27 & 9 & 39 & 39 & 39 & 22 \\
\hline 10 & Sulawesi Selatan & 7 & 68 & 67 & 104 & 104 & 96 & 72 \\
\hline 11 & Sulawesi Tengah & 8 & 60 & 54 & 104 & 104 & 98 & 34 \\
\hline 12 & Gorontalo & 3 & 27 & 27 & 45 & 45 & 39 & 27 \\
\hline 13 & Maluku & 1 & 9 & 9 & 15 & 15 & 13 & 3 \\
\hline 14 & Maluku Utara & 2 & 18 & 18 & 14 & 5 & 24 & 0 \\
\hline 15 & Papua Barat & 1 & 9 & 2 & 15 & 14 & 15 & 0 \\
\hline
\end{tabular}

Keterangan :

$96 \%$ s/d $100 \%$

$80 \%$ s/d $95 \%$

$65 \%$ s/d $79 \%$

$50 \%$ s/d $64 \%$

$<49 \%$

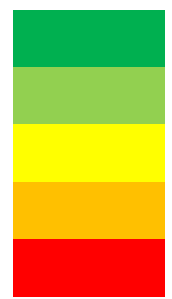


Tabel diatas menunjukkan perbedaan yang kentara antara daerah satu dengan daerah lainnya. Perbedaan pencapaian keberhasilan pada provinsi-provinsi di atas menunjukkan belum meratanya program PAMSIMAS

\section{d. Manfaat Kebijakan Program PAMSIMAS terhadap Pembangunan Kesehatan di Indonesia Dilihat dari Sarana dan Perilaku Masyarakat}

1. Meningkatkan kualitas dan jumlah air yang disalurkan kepada para pelanggan, menghasilkan dampak positif terhadap kesehatan masyarakat.

2. Meluasnya cakupan (berlipat ganda dengan bertambahnya pemakaian) jamban, akan menyebabkan berkurangnya penurunan arus, yang akan meningkatkan kualitas air dan tanah dan mengurangi penyakit yang disebarkan melalui air.

3. Sistem pembuangan yang meningkat, dengan mengurangi pecah/kebocoran pipa, dengan memasang dengan baik sistem pembuangan limbah diseputar sistem air.

4. Meningkatnya pengelolaan pembuangan tinja - walaupun tim PAMSIMAS masih menemukan fakta bahwa praktek pembuangan kotoran tinja yang tidak layak terus menerus menjadi masalah pada masyarakat peserta proyek, mengakibatkan terpolusinya sumber air.

5. Masyarakat dididik untuk menggunakan teknologi sederhana untuk memonitor kualitas air.

6. Meningkatnya kesadaran masyarakat akan masalah kesehatan dan Lingkungan Hidup (yang merupakan komponen utama PAMSIMAS) dilihat dari berkurangnya penyakit diare dan kulit.

e. Faktor Pendukung dan Penghambat dalam Implementasi Program PAMSIMAS

\section{a. Faktor Pendukung}

1. Paradigma baru dalam pendekatan pelaksanaan program PAMSIMAS

Metode yang digunakan adalah metode pemberdayaan yang melibatkan keberadaan masyarakat, memberikan inovasi dan menggugah kreativitas warga melalui kerja kelompok.

2. Kompromi bottom up dan top down

Penyebaran, sosialisasi dan implementasi pendekatan dalam PAMSIMAS merupakan paradigm baru. Dalam pelaksanaan kegiatan PAMSIMAS lebih kearah 
bottom up namun juga terkoordinasi secara to down (campur pemerintah daerah lebih didominasi oleh peran masyarakat, namun terdapat juga proses kompromi antara bottom up dan top down). Semua Instansi terkait termasuk LSM dan Swata yang dikoordinir oleh Bupati, dan peran aktif masyarakat melalui pemicuan dan pemberdayaan, merupakan cara yang strategis dalam penyebaran, sosialisasi dan implementasi kegiatan STBM.

3. Komitmen di semua tingkat

Terdapat kesepakatan komitmen antara pemerintah, LSM, masyarakat, dan berbagai kalangan pejabat di daerah, mulai kabupaten hingga pedesaan, tingkat RW dan RT.

4. Motivasi Penggerak Lokal (Local Champion)

Penggerak lokal tidak hanya natural leader yang ada di masyarakat, tetapi juga di tingkat desa, kecamatan dan kabupaten. Di Instansi mana penggerak local itu, ada di mana-mana tergantung

kondisi lokal. Tidak harus di Dinas Kesehatan, bahkan yang lebih getol ada di
Sosialisasi dilakukan dengan dengan teknik yang menarik dan persuasif Menarik, sugestif, dan mudah dipahami

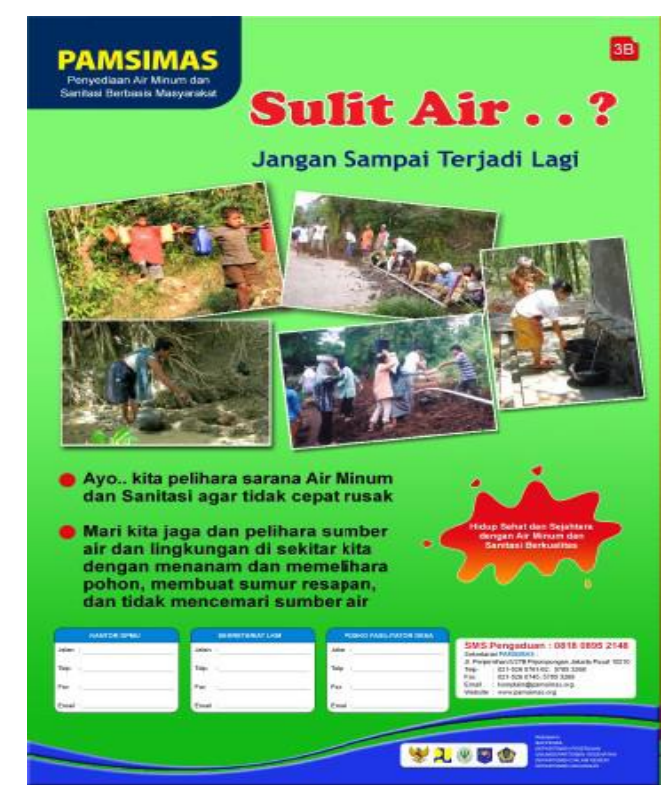

Gambar 4. Contoh poster untuk sosialisasi program PAMSIMAS kepada masyarakat

Bappeda, tidak hanya berasal dari Instansi Pemerintah, bahkan ada yang dari LSM.

5. Sharing Pengalaman antar Daerah

Setelah dipertemukan antar dusun, antar desa, mereka saling kompetisi tidak mau kalah dengan daerah lain. Melalui forum, masyarakat saling belajar 
dan terjadi kompetisi untuk mencapai hal terbaik.

6. Sistem Penghargaan

Terdapat pengahargaan bagi pemerintah dan masyarakat melalui prestasi daerah hingga nasional seperti yang telah didapatkan oleh Kabupaten Pekalongan. Selain itu, pemerintah kerap memberikan dukungan langsung dan penghargaan berupa ucapan-ucapan penggugah semangat. Lewat monitoring dan dukungan langsung dari para pejabat, masyarakat merasa termotivasi. Kedatangan para pejabat di masyarakat dapat memberikan motivasi, sebab mereka sudah bekerja sungguh-sungguh,

memberikan pengorbanan tenaga, pikiran dan uang, mereka ingin dilihat hasil karyanya, ingin dilihat dan ingin juga dihargai.

\section{b. Faktor Penghambat}

1. Hampir sama dengan permasalahan di Papua, factor-factor yang menjadi masalah dalam

2. Anggapan bahwa peningkatan jumlah pasokan air akan menjadikan penanganan masalah limbah (baik air bersih dan limbah rumah tangga) menjadi lebih rumit.

3. Meningkatnya persaingan dalam hal penggunaan sumber air, mengingat sumber air kini menjadi kering akibat global warming.

4. Meluasnya titik cakupan distribusi air akan menyebabkan

bertambahnya kebutuhan dana untuk memonitor sarana yang meluas dan perencanaan yang buruk atau pembangunan fasilitas sanitasi yang tidak layak

5. Dapat menyebabkan pencemaran silang antara jamban dan air sumur, yang berdampak buruk pada kualitas air sumur.

\section{f. Alternatif Solusi}

Dalam implementasinya, PAMSIMAS telah memberikan hasil yang signifikan bagi perkembangan kesehatan masyarakat. Meskipun demikian, ada beberapa aspek yang sekiranya perlu diperhatikan lebih serius dan mendapat kajian mendalam terkait dengan permasalahan dan hambatan yang ada. Berikut ini 
adalah alternatif solusi yang bisa menjadi bahan kajian:

1. PAMSIMAS memberikan kesempatan lebih kepada masyarakat untuk mengembangkan potensinya setelah mendapatkan arahan dari PAMSIMAS. Hal ini mengimplementasikan nilai NPM yaitu rowing is better than steering.

2. Advokasi di Tingkat Propinsi dan Kabupaten

$$
\text { Advokasi dilakukan }
$$
agar lintas sektor, lintas program atau LSM mengetahui tentang Proyek PAMSIMAS termasuk Program Promosi Kesehatan dengan harapan mereka mau untuk melakukan hal-hal sebagai berikut :

a. Mendukung

rencana

kegiatan promosi

kesehatan. Dukungan yang dimaksud bisa berupa dana, kebijakan politis, maupun dukungan kemitraan.

b. Sepakat untuk bersamasama melaksanakan program promosi kesehatan.

b. Mengetahui peran dan fungsi masing-masing sektor/unsur terkait.

3. Ada pembinaan teknis terhadap pelaksanaan program tersebut oleh tim teknis pada tingkat Kecamatan.

4. Menjalin Kemitraan di Tingkat Kecamatan.

Melalui wadah organisasi tersebut Tim Fasilitator harus lebih aktif menjalin kemitraan untuk :
a. Mendukung program kesehatan
b. Melakukan pembinaan teknis
c. Mengintegrasikan program promosi kesehatan dengan program lain yang dilaksanakan oleh Sektor dan Program lain, terutama program Usaha Kesehatan Sekolah, dan program lain di PUSKESMAS.
5. Peningkatan Kapasitas Kelembagaan dan Masyarakat melalui berbagai penyuluhan dan pelatihan mandiri yang didukung pemerintah.

\section{KESIMPULAN}

1. Promosi kesehatan seperti PAMSIMAS bukan hanya proses penyadaran masyarakat atau pemberian dan peningkatan pengetahuan masyarakat tentang kesehatan saja, tetapi juga disertai 
upaya-upaya menfasilitasi perubahan perilaku.

2. PAMSIMAS merupakan salah satu program kesehatan yang dirancang untuk membawa perubahan (perbaikan) baik di dalam masyarakat sendiri maupun dalam organisasi dan lingkungannya (lingkungan fisik, sosial budaya, politik dan sebagainya).

3. Setelah 5 tahun PAMSIMAS berjalan, ada empat faktor yang dapat mempengaruhi masyarakat agar merubah perilakunya, yaitu:

a. Fasilitasi, yaitu bila perilaku yang baru membuat hidup masyarakat yang melakukannya menjadi lebih mudah, misalnya adanya sumber air bersih yang lebih dekat;

b. Pengertian yaitu bila perilaku yang baru masuk akal bagi masyarakat dalam konteks pengetahuan lokal,

c. Persetujuan, yaitu bila tokoh panutan (seperti tokoh agama dan tokoh agama) setempat menyetujui dan mempraktekkan perilaku yang di anjurkan dan d. Kesanggupan untuk mengadakan perubahan secara fisik misalnya kemampuan untuk membangun jamban dengan teknologi murah namun tepat guna sesuai dengan potensi yang di miliki.

\section{SARAN}

1) Bagi pemerintah hendaknya bisa membuat kebijakan yang tidak berbau diskriminasi serta lebih menuju pada kesetaraan fasilitas dan sarana kesehatan terutama air untuk menunjang proses pembangunan yang berkelanjutan.

2) Bagi masyarakat hendaknya lebih berpartisipasi aktif terhadap pembanguanan serta lebih cermat terhadap pengawasan kebijakan yang dibuat oleh pemerintah.

3) Bagi LSM, lembaga donor dan stakeholder lain agar bersedia membantu pemerintah dan masyarakat dalam pembangunan kesehatan dan penyediaan sumber air. 


\section{DAFTAR PUSTAKA}

BPS Jawa Tengah (Online), (www.bpsjateng.go.id, diakses pada 27 April 2011)

BPS Papua Barat (Online), (www.bpspapuabarat.go.id, diakses pada 27 April 2011)

BPS. $2009 . \quad$ (Online), (www.bps.go.id, diakses pada 27 April 2011)

Chandra. 2008. "Pemberdayaan Masyarakat" (Online), (www.pdfsearch.com, diakses pada 27 April 2011)

NN. 2007. Isu, Fakta Pembangunan dan Lingkungan (Online), (www.kemenlh.go.id, diakses pada 27 April 2011)
Red. 2006-2010. Info Pamsimas. (Online), (www.pamsimas.or.id, diakses pada 27 April 2011)

Red. 2009. "Pekalongan Berprestasi" (Online), (www.indonesiatoday.co.id, diakses pada 27 April 2011)

Strategi Kesehatan Indonesia. (Online),(www.kemenkes.go.i d, diakses pada 27 April 2011)

Wahab, Solichin Abdul. 2008. Analisis kebijaksanaan dari formulasi ke implementasi kebijaksanaan negara. Jakarta : PT Bumi Aksara

UNICEF. 2008. "World's health". (Online), (www.unicef.or, diakses pada 27 April 2011) 